УДК 636.12:612, DOI 10.31210/visnyk2018.02.32

(C) 2018

Кабасова I. O., аспірант

Харківська державна зооветеринарна академія

(науковий керівник - кандидат сільськогосподарських наук М. П. Петрушко)

\title{
ЗАСТОСУВАННЯ КОМПЛЕКСУ ЗАХОДІВ ДЛЯ ПІДВИЩЕННЯ СТРЕСОСТІЙКОСТІ СПОРТИВНИХ КОНЕЙ
}

\section{Рецензент - доктор сільськогосподарських наук, професор А. М. Хохлов}

\begin{abstract}
Наведено дослідження з удосконалення системи тренінгу та підготовки коней до змагань з урахуванням фактору стресостійкості з метою більш об'єктивної оцінки робочих якостей коней $i$ проведення якіснішого відбору кращчи тварин у розведення за основною селекційною ознакою - працездатністю. Розроблено комплекс заходів для підвищення стресостійкості під час показових виступів та змагань, який спрямований на поступову адаптацію коней до стресорів. Під час досліджень було встановлено, щзо застосування розробленого комплексу заходів має позитивний вплив на коней сильного врівноваженого інертного та сильного неврівноваженого типів вищої нервової діяльності та не впливає на поведінку коней сильного врівноваженого рухливого типу під час участі у показових виступах та змаганнях.
\end{abstract}

Ключові слова: стресостійкість, тип вищої нервової діяльності, конкур, тренінг коней, показові виступи, працездатність.

Постановка проблеми. Сучасні вимоги, які висуваються до коней на кінно-спортивних змаганнях, досить різноманітні та можуть бути виконані лише тоді, коли кінь цілком підкорюється вершнику. В технології конярства важливе значення має спеціалізований спортивний тренінг, який $є$ невід'ємною частиною селекційної роботи та є подальшим засобом підвищення якості племінної продукції, спеціалізації та загального прогресу породи [2]. Сучасні вимоги до працездатності спортивних коней передбачають постійне покращання якості коней, в тому числі за рахунок удосконалення системи тренінгу.

Аналіз останніх досліджень і публікацій 3 даної проблеми. Робота над створенням систем тренінгу і випробувань ведеться вже багато десятиліть [2]. Однак виявлення спортивних задатків та покращання потенціалу коней залишається на сьогоднішній час нагальною проблемою [5]. Незважаючи на безсумнівні досягнення багатьох конярських спілок та окремих вчених, існуючі системи тренінгу не повністю задовольняють селекціонерів і постійно удосконалюються $[1,7$, $8,10]$.

Усі існуючі системи тренінгу скеровані на розвиток фізичних якостей коней та не враховують впливу стресорів (транспортування, оплески, гучна музика та інші) під час участі у змаганнях та показових виступах $[6,9,11]$. Тренінг спортивних коней має вдосконалювати та розвивати не тільки фізичні якості коня, а й підвищувати адаптаційні можливості та психологічну стійкість коней. Вирішення цих питань $є$ дуже актуальним, бо багато коней не проявляють максимальну працездатність через стан стресу під час змагань, наслідком чого $є$ некоректна оцінка працездатності та недосконалий відбір коней для ведення племінної роботи.

Метою роботи $є$ удосконалення системи тренінгу та підготовки коней до змагань 3 урахуванням фактору стресостійкості з метою більш об'єктивної оцінки робочих якостей коней і проведення якіснішого відбору кращих тварин у розведення за основною селекційною ознакою, а також для отримання більш конкурентоспроможних коней для участі в Національних та Міжнародних турніpax із класичних видів кінного спорту.

Для вирішення даної мети були поставлені наступні завдання:

1. Розробити комплекс заходів для коней, які дозволять знизити рівень реакції на стресфактори під час участі у змаганнях.

2. Встановити наявність чи відсутність кореляції між рівнем прояву стресової реакції та типом ВНД.

3. Надати рекомендації щодо підвищення стресостійкості спортивних коней.

Матеріали і методи досліджень. Дослідження проводилися на 10 головах коней групи конкуру Дергачівської дитячо-юнацької кінноспортивної школи. Дослідження типів ВНД коней проводили за методичними рекомендаціями ВНДІ конярства [3]. Оцінку стресостійкості коней під час показових виступів проводили за розробленою нами методикою [4].

Результати досліджень. Для проведення дослідів було відібрано 10 голів коней групи конкуру Дергачівської дитячо-юнацької кінноспортивної школи, які мали досвід участі у зма- 


\section{СТОРІНКА МОЛОДОГО ВЧЕНОГО}

ганнях 3 подолання перешкод. Середній вік коней становив 8,2 років. На початку досліджень визначили тип ВНД коней. Далі проаналізували результати участі 10 коней у 272 стартах змагань 3 подолання перешкод. Їх результати оцінювались за наступними показниками: середня кількість штрафних очок за старт; відсоток стартів без штрафних очок; відсоток стартів із призовими місцями; відсоток стартів швидше за всіх, але зі штрафом; відсоток виключень зі змагань.

На основі результатів участі коней у змаганнях, з урахуванням типів вищої нервової діяльності та статево-вікових показників нами було сформовано дві рівнозначні групи коней - контрольна та дослідна, по п'ять голів у кожній.

Нами було розроблено комплекс заходів для підвищення стресостійкості під час показових виступів та змагань, який спрямовано на поступову адаптацію коней до стресорів. Стресові ситуаціі, що впливають на коней (транспортування, натовп людей, гучна музика, скупчення коней під час змагань) аналогічні умовам під час показових виступів. Заходи застосовувались диференційовано, в залежності від періоду підготовки (табл. 1).

Під час досліджень нами була розроблена та запатентована покращена модель підпруги, яка дає змогу кріплення додаткових засобів керування на рівні коліна вершника, що в свою чергу дає можливість уникати положення голови та шиї коня ролкюр, додаткового фізичного та психологічного дискомфорту під час тренувань.

Ролкюр є практикою кінного спорту, яка визначається як «гіперзгинання шиї коня», їі заборонено світовим органом управління - Міжнародною федерацією кінного спорту [12]. Під час використання ролкюру шия коня затиснута, кінь нездатен самостійно корегувати свій баланс, не виявляє непокори, через що неможливо визначити моменти, коли він втомився та потребує відпочинку. Гранична форма гіперзгинання, коли з єднання між 2-м і 3-м шийними хребцями розтягнуто 3 максимальною амплітудою, працює подібно до того, як поліцейський захоплює руку підозрюваного, погрожуючи вивихнути іiі або заподіяти біль, щоб він здався. Неможливість позбавитись незручного положення крім фізичного викликає і психологічний дискомфорт, та в разі регулярного застосування ролкюру призводить до стану стресу.

Комплекс заходів для підвищення стресостійкості було впроваджено у систему тренінгу коней дослідної групи з початку підготовчого періоду у грудні 2016 року. Вони частково замінили крокові проводки та звичайний тренінг. Система тренінгу для коней контрольної групи залишилась без змін.

\section{1. Комплекс заходів для підвищення стресостійкості коней}

\begin{tabular}{|c|c|c|c|}
\hline \multirow{2}{*}{ Зміст вправи } & \multicolumn{3}{|c|}{ Тривалість } \\
\hline & $\begin{array}{c}\text { Підготовчий період } \\
\text { (початок) }\end{array}$ & $\begin{array}{c}\text { Підготовчий період } \\
\text { (кінець) }\end{array}$ & Змагальний період \\
\hline $\begin{array}{c}\text { Вмикання аудіо записів музики та } \\
\text { оплесків у стайні безпосередньо } \\
\text { перед годуванням }\end{array}$ & 5 хв./14 днів & - & - \\
\hline $\begin{array}{c}\text { Шагова проїздка по вулицях } \\
\text { населеного пункту }\end{array}$ & $\begin{array}{c}30 \text { хв./2 рази } \\
\text { на тиждень }\end{array}$ & $\begin{array}{c}45 \text { хв./2 рази } \\
\text { на тиждень }\end{array}$ & $\begin{array}{c}30 \text { хв./2 рази } \\
\text { на тиждень } \\
\text { впродовж } 1 \text { місяця }\end{array}$ \\
\hline Ї̈зда риссю по пересіченій місцевості & $\begin{array}{l}20 \text { хв./1 раз } \\
\text { на тиждень }\end{array}$ & $\begin{array}{c}20 \text { хв./2 рази } \\
\text { на тиждень }\end{array}$ & - \\
\hline $\begin{array}{c}\text { Репетиції номерів для показових } \\
\text { виступів за участю } 6 \text { та більше голів } \\
\text { коней }\end{array}$ & $\begin{array}{l}30 \text { хв./2 рази } \\
\text { на тиждень }\end{array}$ & $\begin{array}{c}30 \text { хв./2-3 рази } \\
\text { на тиждень }\end{array}$ & $\begin{array}{c}20 \text { хв./3-5 днів } \\
\text { перед виступами }\end{array}$ \\
\hline $\begin{array}{c}\text { Репетиції номерів для показових } \\
\text { виступів під музичний супровід }\end{array}$ & $\begin{array}{c}15 \text { хв./2 рази } \\
\text { на тиждень }\end{array}$ & $\begin{array}{c}15 \text { хв./2-3 рази на } \\
\text { тиждень }\end{array}$ & $\begin{array}{c}15 \text { хв./3-5 днів } \\
\text { перед виступами }\end{array}$ \\
\hline Участь у показових виступах & $\begin{array}{c}\text { 30-45 хв./1-2 рази } \\
\text { на місяць }\end{array}$ & $\begin{array}{c}30-60 \text { хв./2 рази на } \\
\text { місяць }\end{array}$ & $\begin{array}{c}30-45 \text { хв./1 раз } \\
\text { на місяць }\end{array}$ \\
\hline $\begin{array}{c}\text { Застосування додаткових засобів } \\
\text { керування (за необхідністю) виклю- } \\
\text { чно на підпрузі з додатковими } \\
\text { кільцями }\end{array}$ & $\begin{array}{c}\text { впродовж усього } \\
\text { періоду }\end{array}$ & $\begin{array}{c}\text { впродовж усього } \\
\text { періоду }\end{array}$ & $\begin{array}{c}\text { впродовж усього } \\
\text { періоду }\end{array}$ \\
\hline
\end{tabular}


СТОРІНКА МОЛОДОГО ВЧЕНОГО

\section{2. Критерії оцінки поведінки коней під час показових виступів}

\begin{tabular}{|c|c|c|c|c|c|}
\hline \multirow[b]{2}{*}{ № } & \multirow{2}{*}{$\begin{array}{c}\text { Елементи } \\
\text { поведінки } \\
\text { коня }\end{array}$} & \multicolumn{4}{|c|}{ Оцінка якості виконання } \\
\hline & & $\begin{array}{c}\text { Відмінно, } \\
5 \text { балів }\end{array}$ & $\begin{array}{l}\text { Добре, } \\
4 \text { бали }\end{array}$ & $\begin{array}{c}\text { Задовільно, } \\
3 \text { бали }\end{array}$ & $\begin{array}{c}\text { Незадовільно, } \\
2 \text { бали } \\
\end{array}$ \\
\hline 1 & \begin{tabular}{|c|} 
Реакція на \\
транспорту- \\
вання до місця \\
виступу \\
\end{tabular} & не хвилюється & $\begin{array}{c}\text { трохи хвилюється, } \\
\text { але виконує ко- } \\
\text { манди людини }\end{array}$ & $\begin{array}{c}\text { хвилюється, але } \\
\text { виконує команди } \\
\text { людини після } \\
\text { опору }\end{array}$ & $\begin{array}{c}\text { дуже хвилюється, } \\
\text { відмовляється вико- } \\
\text { нувати команди } \\
\text { людини }\end{array}$ \\
\hline 2 & $\begin{array}{c}\text { Реакція на гуч- } \\
\text { ну музику під } \\
\text { час виступу }\end{array}$ & не реагує & $\begin{array}{l}\text { трохи збуджуєть- } \\
\text { ся, але підкорю- } \\
\text { ється вершнику }\end{array}$ & $\begin{array}{c}\text { виявляє непокору, } \\
\text { але підкорюється } \\
\text { через } 0,1-0,3 \text { хв. }\end{array}$ & $\begin{array}{c}\text { Лякається, тривалий } \\
\text { час або зовсім не } \\
\text { підкорюється }\end{array}$ \\
\hline 3 & $\begin{array}{r}\text { Реакція } \\
\text { лику кіль } \\
\text { гляда } \\
\end{array}$ & не реагує & $\begin{array}{l}\text { трохи збуджуєть- } \\
\text { ся, але підкорю- } \\
\text { ється вершнику } \\
\end{array}$ & $\begin{array}{c}\text { виявляє непокору, } \\
\text { але підкорюється } \\
\text { через } 0,1-0,3 \text { хв. }\end{array}$ & $\begin{array}{r}\text { Лякається, } \\
\text { час або зо } \\
\text { підкорю }\end{array}$ \\
\hline 4 & \begin{tabular}{|c|} 
Реакція на \\
фото- та відео- \\
техніку \\
\end{tabular} & не р & $\begin{array}{l}\text { трохи збуджуєть- } \\
\text { ся, але підкорю- } \\
\text { ється вершнику }\end{array}$ & $\begin{array}{c}\text { виявляє непокору, } \\
\text { але підкорюється } \\
\text { через } 0,1-0,3 \text { хв. }\end{array}$ & $\begin{array}{c}\text { Лякається, тривалий } \\
\text { час або зовсім не } \\
\text { підкорюється }\end{array}$ \\
\hline 5 & $\begin{array}{c}\text { Реакція на ску- } \\
\text { пчення коней в } \\
\text { обмеженому } \\
\text { просторі }\end{array}$ & $\begin{array}{c}\text { не проявляє } \\
\text { агресії }\end{array}$ & \begin{tabular}{|c|} 
проявляє агресію \\
тільки за безпосе- \\
реднього контакту з \\
іншими кіньми
\end{tabular} & $\begin{array}{c}\text { проявляє агресію } \\
\text { за дистанції } \\
\text { 1-1,5 метра до ін- } \\
\text { ших коней }\end{array}$ & $\begin{array}{c}\text { проявляє агресію за } \\
\text { дистанції понад } 2 \\
\text { метри до інших } \\
\text { коней }\end{array}$ \\
\hline 6 & \begin{tabular}{|c|} 
Реакція на \\
оплески та інші \\
шумові подра- \\
зники \\
\end{tabular} & не $\mathrm{p}$ & 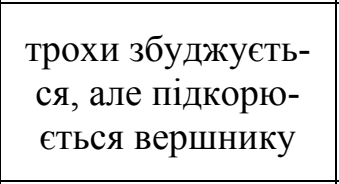 & $\begin{array}{c}\text { виявляє непокору, } \\
\text { але підкорюється } \\
\text { через } 0,1-0,3 \text { хв. }\end{array}$ & $\begin{array}{c}\text { Лякається, тривалий } \\
\text { час або зовсім не } \\
\text { підкорюється }\end{array}$ \\
\hline 7 & $\begin{array}{c}\text { Реакція на змі- } \\
\text { ну погодних } \\
\text { умов (пориви } \\
\text { вітру, дощ) } \\
\end{array}$ & не реагує & $\begin{array}{l}\text { трохи збуджуєть- } \\
\text { ся, але підкорю- } \\
\text { ється вершнику }\end{array}$ & $\begin{array}{c}\text { виявляє непокору, } \\
\text { але підкорюється } \\
\text { через } 0,1-0,3 \text { хв. }\end{array}$ & $\begin{array}{c}\text { Лякається, тривалий } \\
\text { час або зовсім не } \\
\text { підкорюється }\end{array}$ \\
\hline
\end{tabular}

3. Зведена таблиця результатів оцінювання поведінки коней під час участі у показових виступах

\begin{tabular}{|c|c|c|c|c|c|c|c|c|c|c|c|c|}
\hline \multirow{2}{*}{ Кличка } & \multirow{2}{*}{ 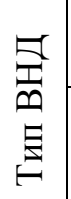 } & \multicolumn{10}{|c|}{$\begin{array}{c}\text { Кількість відсотків позитивних балів, } \\
\text { отриманих під час участі у показових виступах, \% }\end{array}$} & \multirow{2}{*}{$\begin{array}{c}\text { В cep. } \\
3 \mathrm{a} \text { ce- } \\
3 \mathrm{OH}, \%\end{array}$} \\
\hline & & № 1 & № 2 & № 3 & № 4 & № 5 & № 6 & № 7 & № 8 & № 9 & № 10 & \\
\hline \multicolumn{13}{|c|}{ Контрольна група } \\
\hline Cap & $\mathrm{I}$ & 57 & 96,67 & 100,0 & 97,14 & 100,0 & 100,0 & 100,0 & 100,0 & 100,0 & 0 & 98,24 \\
\hline Бpe & $\mathrm{I}$ & 94,29 & 96,67 & 100,0 & 100,0 & 100,0 & 100,0 & 100,0 & 100,0 & 0 & & 07 \\
\hline Бубі & II & 71,43 & 73,33 & 68,00 & 68 & 70,00 & 71,43 & 76,77 & 76,00 & 86,87 & & 74,81 \\
\hline Зна & II & 65.71 & 70,00 & 72,00 & 74,29 & 76,67 & 80,00 & 80,00 & 84,00 & 83 & & 76,87 \\
\hline $\mathrm{CaH}$ & III & 68,57 & 66,67 & 68,00 & 74,29 & 73,33 & 77,14 & 73,33 & 80,00 & 83,33 & & 75,32 \\
\hline $\begin{aligned} \text { В се } \\
\text { по гру }\end{aligned}$ & & $\begin{array}{l}77,71 \\
\pm 5,74 \\
\end{array}$ & $\begin{array}{l}80,67 \\
\pm 6,22 \\
\end{array}$ & $\begin{array}{l}81,60 \\
\pm 7,55 \\
\end{array}$ & $\begin{array}{l}82,86 \\
\pm 6,51 \\
\end{array}$ & $\begin{array}{r}84,00 \\
\pm 6,62 \\
\end{array}$ & $\begin{array}{l}85,71 \\
\pm 5,99 \\
\end{array}$ & $\begin{array}{l}86,02 \\
\pm 5,80 \\
\end{array}$ & $\begin{array}{l}88,00 \\
\pm 5,06 \\
\end{array}$ & $\begin{array}{l}90,67 \\
\pm 3,85 \\
\end{array}$ & $\begin{array}{c}91,43 \pm \\
3,61 \\
\end{array}$ & $\begin{array}{c}84,86 \pm \\
5,64 \\
\end{array}$ \\
\hline \multicolumn{13}{|c|}{ Дослідна група } \\
\hline A0001 & $\mathrm{I}$ & 94,29 & 100,0 & 100,0 & 100,0 & 100,0 & 100,0 & 100,0 & 100,0 & 100,0 & 100,0 & 99,43 \\
\hline Рембран & $\mathrm{I}$ & 88,57 & 90,00 & 100,0 & 97,14 & 100,0 & 100,0 & 100,0 & 100,0 & 100,0 & & 97,57 \\
\hline & II & 74,29 & 76,67 & 80,00 & 82,86 & 83, & 88,57 & 90,00 & 96,00 & 93,33 & & 86,22 \\
\hline Кібс & III & & & 72,00 & 77,14 & & $0 J, / 1$ & 86,67 & 92,00 & 96,67 & 94,29 & \\
\hline & 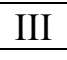 & 77,14 & 80,00 & 84,00 & 85,71 & 86,67 & 88,57 & 86,67 & 92,00 & 96,67 & 97,14 & 87,46 \\
\hline $\begin{array}{l}\text { В cep. } \\
\text { по групі }\end{array}$ & & $\begin{array}{l}80,00 \\
\pm 5,11\end{array}$ & $\begin{array}{l}83,33 \\
\pm 5,27\end{array}$ & $\begin{array}{l}87,20 \\
\pm 5,57\end{array}$ & $\begin{array}{l}88,57 \\
\pm 4,33\end{array}$ & $\begin{array}{l}90,67 \\
\pm 3,86\end{array}$ & $\begin{array}{l}92,57 \\
\pm 3,08\end{array}$ & $\begin{array}{l}92,67 \\
\pm 3,05\end{array}$ & $\begin{array}{l}96,00 \\
\pm 1,79\end{array}$ & $\begin{array}{l}97,33 \\
\pm 1,25\end{array}$ & $\begin{array}{c}97,71 \pm \\
1,07\end{array}$ & $\begin{array}{c}90,61 \pm \\
3,34\end{array}$ \\
\hline
\end{tabular}


Під час досліджень нами було виділено сім основних подразників, які, на нашу думку, впливають на стресовий стан коней під час участі у показових виступах та змаганнях. Для отримання показників рівня прояву стрес-реакції під час показових виступів були розроблені критерії поведінки коней, за якими вони були оцінені після кожного виступу (табл. 2).

Спостереження та оцінювання контрольної та дослідної груп велись у підготовчому періоді під час участі коней у 6 виставах та у змагальному періоді під час участі коней у 4 виставах. Результати всіх виступів коней як дослідної, так і контрольної груп, виражені у відсотках від максимально можливої кількості позитивних балів, представлені у таблиці 3.

Як ми бачимо, результати коней врівноваженого рухливого типу вищої нервової діяльності дослідної та контрольної групи суттєво відрізняються від результатів інших коней та складають у цілому майже 100 \%. Їх поведінка адекватна і за умов існуючої в господарстві системи тренінгу, і під час застосування комплексу заходів для підвищення стресостійкості коней. Тобто впливу розробленого комплексу заходів для підвищення стресостійкості на коней врівноваженого рухливого типу вищої нервової діяльності немає, їх поведінка не потребує корекції. Та їх результат значною мірою впливає на середній результат по групі. Під час порівняння середнього результату дослідної та контрольної груп можна побачити, що вже під час першого виступу коні дослідної групи були краще адаптовані до стресфакторів, ніж коні контрольної групи. Різниця між їх результатами становить 2,29\%. Надалі обидві групи покращують свої результати, тобто існуюча в господарстві система підготовки коней також дає позитивний вплив на стресостійкість коней, але різниця між групами поступово збільшується, дослідна група прогресує швидше. Різниця між групами наприкінці сезону становить $6,28 \%$, а загальна за весь сезон становить 5,75\%.

Якщо провести аналіз результатів коней сильного врівноваженого інертного та сильного неврівноваженого типів вищої нервової діяльності контрольної та дослідної груп (табл. 4), ми бачимо ще більший вплив розробленого комплексу заходів на коней дослідної групи. Різниця між результатами під час першого виступу становить 3,81\%. Починаючи 3 3-го виступу, ми отримуємо достовірну різницю між результатами двох груп. Подальша адаптація дослідної групи більш повна, вони покращили свій результат до 96,19\% під час останнього виступу проти результату 85,71 \% контрольної групи. Різниця між ними становить 10,48 \%. Різниця між середнім результатом за сезон дослідної та контрольної груп становить 9,67\%.

Надалі були систематизовані та проаналізовані результати участі коней контрольної та дослідної груп у змаганнях спортивного сезону 2017 року. Їх результати оцінювались за тими ж показниками, що і на початку підготовчого періоду. Результати даного дослідження наведені у таблиці.

\section{4. Результати оцінювання поведінки коней сильного врівноваженого інертного та сильного неврівноваженого типів вищьї нервової діяльності}

\begin{tabular}{|c|c|c|c|c|c|c|c|c|c|c|c|c|}
\hline \multirow{2}{*}{ Кличка } & \multirow{2}{*}{ 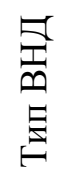 } & \multicolumn{10}{|c|}{$\begin{array}{c}\text { Кількість відсотків позитивних балів, отриманих під час участі у показових } \\
\text { виступах, \% }\end{array}$} & \multirow{2}{*}{$\begin{array}{l}\text { В сер. } \\
\text { за се- } \\
\text { 3он, } \%\end{array}$} \\
\hline & & №1 & №2 & №3 & №4 & №5 & №6 & №7 & №8 & №9 & №10 & \\
\hline \multicolumn{13}{|c|}{ Контрольна група } \\
\hline Бубна & II & 71,43 & 73,33 & 68,00 & 68,57 & 70,00 & 71,43 & 76,77 & 76,00 & 86,87 & 85,71 & 74,81 \\
\hline Знахар & III & 65,71 & 70,00 & 72,00 & 74,29 & 76,67 & 80,00 & 80,00 & 84,00 & 83,33 & 82,86 & 76,87 \\
\hline Сантес & III & 68,57 & 66,67 & 68,00 & 74,29 & 73,33 & 77,14 & 73,33 & 80,00 & 83,33 & 88,57 & 75,32 \\
\hline $\begin{array}{l}\text { В cеp. } \\
\text { по групі }\end{array}$ & & $\begin{array}{l}68,57 \\
\pm 1,65\end{array}$ & $\begin{array}{l}70,00 \\
\pm 1,92\end{array}$ & $\begin{array}{c}69,33 \pm \\
1,33\end{array}$ & $\begin{array}{l}72,38 \\
\pm 1,91\end{array}$ & $\begin{array}{l}73,33 \pm 1 \\
, 93\end{array}$ & $\begin{array}{c}76,19 \pm \\
2,52\end{array}$ & $\begin{array}{l}76,70 \\
\pm 1,93\end{array}$ & & & $\begin{array}{c}85,71 \pm \\
1,65\end{array}$ & $\begin{array}{l}75,67 \\
\pm 0,62\end{array}$ \\
\hline \multicolumn{13}{|c|}{ Дослідна група } \\
\hline Румба & II & 74,29 & 76,67 & 80,00 & 82,86 & 83,33 & 88,57 & 90,00 & 96,00 & 93,33 & 97,14 & 86,22 \\
\hline Кіборг & III & 65,71 & 70,00 & 72,00 & 77,14 & 83,33 & 85,71 & 86,67 & 92,00 & 96,67 & 94,29 & 82,35 \\
\hline Сенс & III & 77,14 & 80,00 & 84,00 & 85,71 & 86,67 & 88,57 & 86,67 & 92,00 & 96,67 & 97,14 & 87,46 \\
\hline $\begin{array}{l}\text { В cер. } \\
\text { по групі }\end{array}$ & & $\begin{array}{c}72,38 \pm \\
3,43\end{array}$ & $\begin{array}{l}75,56 \\
\pm 2,94\end{array}$ & $\begin{array}{c}78,67 \pm \\
3,53^{*}\end{array}$ & $\begin{array}{l}81,90 \\
\pm 2,52 *\end{array}$ & $\begin{array}{c}84,44 \pm 1 \\
, 11 * *\end{array}$ & $\begin{array}{l}87,62 \\
\pm 0,95^{*}\end{array}$ & $\begin{array}{c}87,78 \pm \\
1,11^{* *}\end{array}$ & $\begin{array}{l}93,33 \pm \\
1,33 * *\end{array}$ & $\begin{array}{c}95,56 \\
\pm 1,11 \\
* *\end{array}$ & $\begin{array}{c}96,19 \pm \\
0,95 \\
* *\end{array}$ & $\begin{array}{c}85,34 \\
\pm 1,54^{*} \\
*\end{array}$ \\
\hline
\end{tabular}

Примітка: * $\mathrm{P}<0,05 ; * * \mathrm{P}<0,01$. 


\section{СТОРІНКА МОЛОДОГО ВЧЕНОГО}

5. Результати участі коней контрольної та дослідної груп за змагальний сезон 2017 року

\begin{tabular}{|c|c|c|c|c|c|c|c|c|c|}
\hline $\begin{array}{c}\text { № } \\
3 \backslash \Pi\end{array}$ & Кличка & $\begin{array}{c}\text { Рік } \\
\text { наро- } \\
\text { дження }\end{array}$ & Стать & $\begin{array}{c}\text { Тип } \\
\text { ВНД }\end{array}$ & $\begin{array}{c}\text { Середня } \\
\text { кількість } \\
\text { штр. } \\
\text { очок за } \\
\text { старт }\end{array}$ & $\begin{array}{l}\text { \% стартів } \\
\text { без штра- } \\
\text { фних очок }\end{array}$ & $\begin{array}{c}\text { \% стартів } 3 \\
\text { призовими } \\
\text { місцями }\end{array}$ & $\begin{array}{c}\text { \% стартів } \\
\text { швидше за } \\
\text { всіх, але зі } \\
\text { штрафом }\end{array}$ & $\begin{array}{c}\text { \% ви- } \\
\text { ключень } \\
\text { зі зма- } \\
\text { гань }\end{array}$ \\
\hline \multicolumn{10}{|c|}{ Дослідна група } \\
\hline 1 & Хоббі & 2008 & коб. & I & 1,81 & 58,06 & 58,06 & 10,34 & 6,89 \\
\hline 2 & Рембрант & 2008 & мер. & I & 2,57 & 51,43 & 40,00 & 11,43 & 5,71 \\
\hline 3 & Румба & 2012 & коб. & II & 2,26 & 64,52 & 54,84 & 9,68 & 0,00 \\
\hline 4 & Кіборг & 2010 & мер. & III & 2,12 & 63,64 & 51,52 & 6,06 & 0,00 \\
\hline 5 & Сенс & 2006 & жер. & III & 3,29 & 60,71 & 60,71 & 17,86 & 0,00 \\
\hline \multicolumn{5}{|c|}{ Разом по групі } & $\begin{array}{c}2,41 \pm \\
0,25\end{array}$ & $\begin{array}{c}59,67 \pm \\
2,35^{*}\end{array}$ & $\begin{array}{c}53,03 \pm \\
3,60^{*}\end{array}$ & $\begin{array}{c}11,07 \pm \\
1,92\end{array}$ & $\begin{array}{c}2,52 \pm \\
2,46\end{array}$ \\
\hline \multicolumn{10}{|c|}{ Контрольна група } \\
\hline 1 & Сарбона & 2008 & коб. & I & 1,78 & 61,11 & 50,00 & 11,11 & 5,56 \\
\hline 2 & Бренд & 2007 & жер. & I & 2,48 & 48,00 & 40,00 & 16,00 & 4,00 \\
\hline 3 & Бубна & 2012 & коб. & II & 2,65 & 52,17 & 39,13 & 8,70 & 0,00 \\
\hline 4 & Знахар & 2010 & мер. & III & 2,46 & 50,00 & 39,29 & 21,43 & 3,57 \\
\hline 5 & Сантес & 2007 & мер. & III & 4,40 & 46,15 & 46,15 & 23,08 & 3,85 \\
\hline \multicolumn{5}{|c|}{ Разом по групі } & $\begin{array}{c}2,75 \pm \\
0,44\end{array}$ & $\begin{array}{c}51,49 \pm \\
2,61\end{array}$ & $\begin{array}{c}42,91 \pm \\
2,20\end{array}$ & $\begin{array}{c}16,06 \pm \\
2,80\end{array}$ & $\begin{array}{c}3,40 \pm \\
1,03\end{array}$ \\
\hline
\end{tabular}

Примітка: * $\mathrm{P}<0,05$.

Аналізуючи результати, представлені в даній таблиці, ми бачимо, що коні дослідної групи мають на 0,34 бали менше штрафних очок за старт, на $8,18 \%$ більше стартів без штрафних очок, на 10,12\% більше стартів із призовими місцями, на 4,99\% менше стартів, що були пройдені швидше за всіх, але зі штрафом, та на $0,88 \%$ менше виключень зі змагань у порівнянні 3 кіньми контрольної групи. Тобто коні дослідної групи показали кращі результати за всіма показниками, проте достовірні дані отримані за показником кількості стартів без штрафних очок та за відсотком стартів 3 призовими місцями.

Висновок. 3 отриманих даних можна зробити висновки про позитивний вплив розробленого комплексу заходів для підвищення стресостійкості на коней сильного врівноваженого інертного та сильного неврівноваженого типів вищої нервової діяльності. Комплекс заходів для підви-

\section{БІБЛІОГРАФІЯ}

1. Галенкова О. В., Сергиенко Г. Ф. Тренинг спортивных лошадей с учетом их психологии // Коневодство и конный спорт. 2012. №5. С. 1718.

2. Дорофеев В. Н., Дорофеева Н. В. Наставление по заводскому спортивному тренингу. ВНИИК, 2003. 30 c. щення стресостійкості не має впливу на коней врівноваженого рухливого типу вищої нервової діяльності, їх поведінка не потребує корекції.

Результати проведених досліджень дають можливість удосконалити систему тренінгу для коней сильного врівноваженого інертного та сильного неврівноваженого типів вищої нервової діяльності на різних періодах підготовки коней 3 метою підвищення їх стресостійкості в умовах змагальної діяльності; проводити більш якісний відбір кращих тварин у розведення за основною селекційною ознакою - працездатністю; отримувати більш конкурентоспроможних коней для участі в Національних та Міжнародних турнірах із класичних видів кінного спорту, що підвищить рівень реалізації коней, цінові показники та економічну ефективність роботи племінних господарств у цілому.

3. Изучение топологических свойств и функционального состояния центральной нервной системы лошадей. Методическое руководство / Л. Х. Ашибоков, И. Л. Брейтшер, Г. Г. Карлсен [и др.]. Нальчик, 1990. 207 с.

4. Кабасова I. О., Петрушко М. П. Методика оцінки стресостійкості спортивних коней. Мето- 
дичні рекомендації. - Харків : ХДЗВА, 2018. $23 \mathrm{c}$.

5. Мирось В. В., Головко В. А., Ткачева И. В. Коневодство : учебное пособие. - Харков, 2007. $185 \mathrm{c}$.

6. Рудак А. Н., Горбуков М. А., Герман Ю. И. Изучение стресс-чувствительности лошадей верховых пород // Коневодство и конный спорт. - 2016. - №3. - С. 17-18.

7. Сергиенко Г. Ф., Иванова Н. П. Функциональное состояние лошадей разного типа ВНД при различных системах тренинга // Коневодство и конный спорт. - 2011. - №3. - С. 19-20.

8. Сергиенко С. С., Иванова Н. В., Сергиенко $\Gamma$. $Ф$. Усовершенствованная система спортивно-

\section{ANNOTATION}

Kabasova I. O. Application of the complex of actions to increase stress resistance of sports horses.

In this work studies have been conducted to improve the training system and preparation of horses for competitions, taking into account the stressstability factor in order to more objective assessment of the working qualities of horses and conducting a better selection of the best animals in breeding on the main selection criterion - ability to work. A set of measures was developed to increase the stress resistance during demonstrations and competitions, aimed at gradually adapting horses to stressors.

For conducting experiments, 10 heads of horses of the jumping group of Dergachiv Children and Youth Equestrian Sports School, who had the experience of participating in the competition to overcome obstacles, were selected. The average age of horses was 8.2 years. Research of the types of HND of horses was carried out according to the methodical recommendations of VNIII horse breeding. Assessment of the stress resistance of horses during demonstrative performances was carried out according to the methodology developed by us.

Based on the results of the participation of horses in competitions, taking into account the types of higher nervous activity and sex-age indicators, we have formed two equivalent groups of horses - control and experimental, with five horses in each. A го тренинга молодняка // Коневодство и конный спорт. - 2012. - №2. - С. 15-17.

9. Стресс и адаптация сельскохозяйственных животных в условиях индустриальных технологий / Ф. И. Фурдуй, Е. И. Штирбу, Ф. А. Струтинский [и др.]. - Кишинев, 1992. - 224 с.

10. Шрейнер И. Обучение лошадей // Коневодство и конный спорт. -2001 . - №3. - С. 12.

11. Deaton C. M., Marlin D. J. Exerciseassociated oxidative stress. Clin Tech Equine Pract. - 2003. - №2. - P. 278-291.

12. Butcher $A$. Rollkur row under discussion by FEI // Horse and Hound. - 2009.11.12.

set of measures for increasing stress resistance was introduced into the training system of horses of the experimental group from the beginning of the preparatory period in December 2016.

During the research, it was found that the application of the developed set of measures has a positive effect on the horses of strong, balanced inert and severe unbalanced types of higher nervous activity and does not affect the behavior of horses of a strong, balanced, mobile type during participation in demonstrative performances and competitions.

The results of the conducted researches allow: to improve the training system for horses of a strong balanced inert and severe unbalanced types of higher nervous activity at different periods of horses training in order to increase their stress resistance in conditions of competitive activity; to conduct a more qualitative selection of the best animals in breeding by the main selection criterion - ability to work; to receive more competitive horses for participation in National and International competitions for classical equestrian sport, which will increase the level of implementation of horses, price indices and the economic efficiency of the work of breeding farms in general.

Key words: stress resistance, type of higher nervous activity, competition, training of horses, demonstrative performances, ability to work. 